\title{
Leipzig 2003
}

\author{
By Ron Holloway
}

Spring 2004 Issue of KINEMA

The $46^{\text {th }}$ Leipzig International Festival for Documentary and Animation Films (14-19 October 2003) - the tenth under retiring festival director Fred Gehler - went down in the books as one of the best so far as politically relevant programming was concerned. Rithy Panh's S21 - La machine de mort Khmère Rouge (S21 - The Khmer Rouge Killing Machine, France) was awarded both the Golden Dove for Best Long Documentary by the International Jury and the FIPRESCI Prize by the International Critics. First seen at Cannes in the Official Program as a Special Screening, S21 is currently making the rounds of key international film festivals - after Leipzig it was booked for the Viennale and the London Film Festival.

Running at 100 minutes, its plodding pace demands the complete attention of the viewer and makes for a quite horrifying experience as the story unfolds. S21 refers to the site of the genocide museum at Tuol Sleng in a residential neighbourhood of Phnom Penh. Here, in what was previously a school building, circa 12,000 prisoners were documented, interrogated, and then exterminated. Only a few survived - among them the painter Van Nath, who in S21 returns to the site of his internment with the paintings that helped him to survive during his ordeal in the prison. He is accompanied by former guards and executioners, who during the height of the tyrannical Pol Pot regime (1975-79) were callow youths recruited from the fighting front at a price: either do the dirty work or join the victims.

S21 opens with a visit to one of these ex-guards. He is shown at home with his parents, a broken man who can hardly sleep and suffers stoically the indignation of his mother's rancour under the eyes of the camera. Later, in the compound, Van Nath relentlessly interrogates the guards as to their motives - often including rape and torture of the prisoners - down to the final ritual of the executions. The guards, now the victims under interrogation, respond pretty much as one would expect: they give the answers Van Nath wants to hear and find no words of remorse. By contrast, Van Nath himself has to live with a bitter truth: he himself had given the names of innocent friends, relatives, and colleagues to the interrogators to order to live a few days longer. As for the thousands who died, their photographs now line the walls of the school at Tuol Sleng genocide museum for all to see.

The moral question of war and killing was raised again in Alexander Rastorguyev's Chisty Chetverg (Clean Thursday, Russia). Shot in Chechnya, the title refers to a "steam-train" that arrives once a week to allow combat Russian soldiers the opportunity to take a bath before returning to the front. Presented in its original context (government censors have since demanded cuts), Clean Thursday is remarkable for the frankness of the young soldiers' dialogue - usually bitter, often vulgar in expression, and sometimes unrepenting for the cruel treatment of captured snipers, among them young women. The war in Chechnya, viewed from this paradoxical distance, is all the more vivid because the soldiers cannot wash away the dirt of their deeds along the mud on their skin and uniforms. Clean Thursday was awarded the Ecumenical Prize and the MDR (Mitteldeutscher Rundfunk) Film Prize.

A documentary from Israel also raised the same moral questions about the sense of an endless conflict without a resolution in sight. Tamar Wishnitzer-Haviv's The Ranch Across - aka Life for Land - was commissioned by Israeli television to chronicle the feelings of both a Jewish and a Palestinian community following a pair of killings in the occupied Palestinian territory. The young woman filmmaker visits a Jewish settlement, where a horse ranch had been carved out of the occupied territory by a family of radical Orthodox Jews. Back in 1998, the inevitable happened: the husband was shot, a Palestinian was killed, and the conflict has since soared under present militant policies. The focus in The Ranch Across is on the wife and mother whose husband had been killed. When the widow states on camera that she wants to renounce the settler ideology for the sake of her family, her family and neighbours try to convince her to stay - although this would mean to drive her boys daily to school "on the other side of the fence" with a gun resting on her lap. Life for Land was awarded the ver.di (Media Trade Union) Prize and received a Special Mention from the International Jury.

Bengt Jägerskog's Hugo och Rosa (Sweden), a television special shot at intervals between 1992 and 2002, 
chronicles the last years of two senior citizens, the siblings Hugo and Rosa, who still live in the little red house in which they were born. Photos in a family album from the 1930s reveal that the Gunby farm has hardly changed over the years - in fact, it's still without electricity or running water! But the pair revel in this kind of simplicity, as well as attending church, baking bread, and entertaining themselves on Rosa's accordion. As the film progresses, we see that old age is forcing reluctant changes in their lives: Hugo, close to his 100th birthday, falls seriously ill, then recovers - enough reason, however, for the social welfare authorities to relocate the siblings to a nursing clinic in Stokholm, where they are given an apartment to share. When Rosa dies, Hugo is seen sitting at her bedside. Later, when Hugo senses in his bones that his time too has arrived, he simply opens the window of the apartment, says "Rosa, I'm coming," and lies down to die. Hugo and Rosa is one of those human documents with a moral - a reminder that the "good old days" in rural Sweden were far more family-centred and community-sharing than is the rule in today's existence. The film well deserved the Silver Dove for Long Documentary by the International Jury.

Pea Holmquist's Min Far - Inspektörn (My Father - The Inspector, Sweden), a short 15-minute documentary about the Swedish welfare system, amuses with its insights to just how the system worked in the postwar years and how a single individual gave it a human face. Back in the late 1950s, when the filmmaker was 10-years-old, his father bought him an $8 \mathrm{~mm}$ camera and asked him to accompany him on his rounds in his free time. The idea was to help make the work of Sjunne Holmquist, a state employee whose job was to inspect the slums of Kristianstad, a bit more personal and effective. But it also helped to launch the boy's filmmaking career at an early age, to say nothing of providing Sjunne with photos and film footage of his favourite welfare cases for a popular lecture series when retirement rolled around. My Father - The Inspector was awarded the Golden Dove for Best Short Documentary.

Over the years, Russian documentarist Sergei Loznitsa has been a welcomed guest at the Leipzig DOKfestival. His keen, discerning eye for the foibles of Russian everyday life has won him plaudits and awards: Today We Are Going to Build a House (1996) and Life, Autumn (1998, both with Marat Magambetov), then Train Station (1999), Settlement (2001), and Portrait (2002). In Peyzazh (Landscape), his latest Leipzig entry, the setting is a bus-stop in a provincial town on a cold winter day. The camera pans slowly across the "landscape" of faces while, on a separate recording for the soundtrack, we hear people - young and old - talking about their woes and worries and will to survive by living each day as it comes. Finally, the bus arrives - an hour late - exactly the amount of time Loznitsa required to shoot this remarkable candid-camera documentation. Landscape was awarded the Special Prize for Best Camera by the International Jury.

Along the same candid-camera lines, Viktor Asliuk's Kola (The Wheel, Byelorussia) takes the pulse of a village far off the beaten path. Inhabited only by old people - save a young couple, who have chosen this place to raise a family - the old folks wait for the arrival of a shop-on-wheels that passes through the small community once a week with groceries and home items. Asliuk's short documentary given Special Mentions by both the International Jury and the Ecumenical Jury, is remarkable for its tongue-in-cheek humour and sensitive approach to conditions in an nearly abandoned village. Rujian Li's 9 Kilometer Road in the Sea (China) also captured the routine of life in an isolated village. The scene is Haiyang on the Liaodong peninsula in the northeast province of Manchuria. The "9 Kilometer Road" refers to a seapath that appears every day when the tide is out, immediately prompting hundreds of villagers to scurry off afoot, some on bicycle, with empty bags on their back. Their destination is a bank of shells, which are dug from the ocean floor and packed in the bags before the tide returns to cover the road and prevent return. Since these shells are the only source of income for the villagers, the passageway has a mythical connotation - somewhat like the Biblical story of the parting of the Red Sea.

Some documentaries at the DOKfestival could easily be classified as fiction-documentaries. The opening night presentation of Martin Sulík's Klíc $k$ urcováni trpaslíku aneb Posledni cesta Lemuela Gullivera (The Key to Determining Dwarfs, or The Last Trip of Lemuel Gulliver, Czech Republic), for instance. First seen at the International Forum of Young Cinema at the Berlinale, then awarded the Grand Prize at the GoEast Film Festival in Wiesbaden, this innovative fictitious journey through the life and times of writer-director Pavel Jurácek - featuring Pavel's son, Marek Jurácek, in the lead role - explicitly intends to rub out the lines between fiction and documentary. Also, Chris Wright and Stefan Kolbe's Technik des Glücks (The Progress of Happiness, Germany) opens with a British bomber on its way on a mission during the Second World War to wipe out the electrical power station at Zschornewitz, then subtly shifts to footage made by amateur 
filmmakers who had worked at the coal-fed power plant and filmed its work days and company gatherings before it was officially closed. The Progress of Happiness was given a Special Mention by the FIPRESCI Jury.

Investigative journalism has traditionally enjoyed a special focus at Leipzig. In Lutz Dambeck's Das Netz (The Net, Germany) the director visits key political and industrial officials in the United States in an effort to get behind the reasons for the string of letter-bombs sent by the "Unabomber" Ted Kaczynski to fellow academics at elite universities and research institutions. Although little new information is given, still we are taken on a whirlwind tour of cybernetic research used for military purposes and psychological experiments. And in José Padilha's Omnibus 174 (Bus 174, Brazil) the viewer partakes in an on-the-spot investigative report into the background for the hijacking of a bus in Rio de Janeiro by a down-and-out "street kid" that ends in the hijacker's death, comes across as a crime thriller and a social drama. Often, Padilha veers away from the TV "event" to show that police brutality in the past is a prime reason for hijacking, for Rio street-kids are systematically denied outlets to better their existence.

The Leipzig DOKfestival was far more than just the 16 sociopolitical documentaries in competition. Among its sidebar programs was an all-embracing historical review of "Stalin's Traces in Russian History". Another series on "Aspects of Africa" was sponsored by Planet TV, the French cable documentary channel. Russian camerawoman Irina Uralskaya, a jury member, was honoured with a retrospective tribute, as was the 14-film homage to German documentarist Peter Schamoni. The German Federal Film Archive reviewed the history of Soviet documentary in a "View/ Counter-View" series. All this, and a full-scale animation festival with its own competition, plus an all-night "first flush" program of shorts made by local amateur filmmakers and video enthusiasts. Simply too much for one week, you might say, but that's how Leipzig has developed over the last decade under the aegis of Fred Gehler.

As for the animation program, one of the festival pillars, no less than 174 cartoons and "AnimaDoc" films from 37 countries were programmed by Otto Adler in the Passage Kinos - often to overflow crowds. The Golden Dove was awarded to Oksana Cherkasova's Chelovek s luny (The Man from the Moon, Russia), a delicately sketched, ethereal tale about the floundering hopes of a Russian scientist whose life passes before his eyes before the final curtain falls. Like Sergei Loznitsa, Oksana Cherkasova is a familiar face at Leipzig her misty, dreamlike Nyura's Bath was awarded a Silver Dove at the 1995 Leipzig festival. The Silver Dove went to Koji Yamamura's Atama Yama (Mt. Head, Japan), an caricatured animated version of a traditional tale about a cherry tree sprouting out of the head of a stingy man after the miser had swallowed some cherry seeds.

Finally, a word about a special screening. Benjamin Geissler's Bilder finden (Finding Pictures, Germany) documents the search for plastered-over frescoes painted by Jewish writer Bruno Schulz (1892-1942) in a villa in the Ukrainian town of Drohobycz (formerly Poland), where Schulz was once employed by a Gestapo officer to decorate his children's bedroom. Once these fairy-tale-like frescoes were found in 1999, to be exposed for historians and the public, two fragments were illegally removed in 2001 and transported to Jerusalem by members of the Yad Vashem Holocaust Remembrance Authority. Thus this highly informative documentary - featuring Benjamin's father Christian Geissler, who had originally initiated the search - stops midway through the story just it reaches its most provocative point. Since the New York Times has also taken an interest in resolving the riddle of why the frescoes have not remained in the place of origin, Finding Pictures may one day have a sequel.

The DOKfestival paid tribute to the late Klaus Wischnewski, a former member of the selection committee, with a memorial page in the 220-page catalogue titled Ein Mensch verlässt uns" (A Person Leaves Us). An autobiographical note from Wischnewski's own account of what happened in 1965/66, when decisions were taken by GDR Party officials at the $11^{\text {th }}$ Plenum of the SED Central Committee to shelf much of that year's production, documents once again how difficult it was for key individuals to maintain positions of integrity during these trying times. The article is headed "Die zornigen jungen Männer von Babelsberg" (The Angry Young Men of Babelsberg). Read it at your leisure.

Good luck, Fred Gehler! We wish you well in retirement, if truly you will ever retire. We, too, have many fond memories of past DOKfestivals. And the very best to Claas Danielsen, the new festival director. 


\section{References}

\section{AWARDS}

Golden Dove, Long Documentary

S21 - La machine de mort Khmer Rouge (S21 - The Khmer Rouge Killing Machine, France), Rithy Panh

Silver Dove, Long Documentary

Hugo och Rosa (Hugo and Rosa, Sweden), Bengt Jägerskog

Special Mention, Long Documentary

The Ranch Across (Israel), Tamar Wishnitzer-Haviv

Golden Dove, Short Documentary

Min Far - Inspektörn (My Father - The Inspector, Sweden), Pea Holmquist

Silver Dove, Short Documentary

Fall into Half-Angel (Ireland), Roisin Loughrey

Special Mention, Short Documentary

Kola (The Wheel, Byelorussia), Viktor Asliuk

Prize for Best Camera

Peyzazh (Landscape, Russia), Sergei Loznitsa

Golden Dove, Animation

Celovek s luny (The Man from the Moon, Russia), Oksana Cherkasova

Silver Doves, Animation

Atama Yama (Mt. Head, Japan), Koji Yamamura

Special Mentions, Animation

Automania (Car Craze, Netherlands), Evert de Beijer

Harvie Krumpet (Australia), Adam Benjamin Elliot

Krasnye vorota rasemon (The Red Gates of Roshomon, Russia), Alexander Tatarsky, Valentin Telegin

Sparkasse Leipzig Prize

Fast Film (Austria/Luxembourg), Virgil Widrich

MDR (Mitteldeutscher Rundfunk) Film Prize

Chisty Chetverg (Clean Thursday, Russia), Alexander Rastorguyev

FIPRESCI (International Critics) Prize

S21 - La machine de mort Khmer Rouge (S21 - The Khmer Rouge Killing Machine, France), Rithy Panh

Special Mention

Technik des Glücks (The Progress of Happiness), Chris Wright, Stefan Kolbe

Ecumenical Jury

Chisty Chetverg (Clean Thursday, Russia), Alexander Rastoguyev

Special Mention

Kola (The Wheel, Byelorussia), Viktor Asliuk

ver.di (Media Trade Union) Prize

The Ranch Across (Israel), Tamar Wishnitzer-Haviv

Leipzig Youth Jury Prize

Story (Germany), Dana Ranga

Mephisto-97.6 Audience Prize

Le portefeuille (The Wallet, France/ Belgium), Vincent Bierrewaerts 


\section{Author Information}

Ron HOLLOWAY (1933-2009) was an American critic, film historian, filmmaker and correspondent who adopted Europe as his home in the early fifties and spent much of his life in Berlin. He was an expert on the study of German cinema and against all odds produced, with his wife Dorothea, the journal German Film, keeping us up-to-date with the work of directors, producers and writers and the showing of German films around the world.

In 2007, Ron Holloway and his wife were awarded the Berlinale Camera Award. Ron also received the Bundesverdienstkreuz (German Cross of Merit), Polish Rings, Cannes Gold Medaille, the American Cinema Foundation Award, the Diploma for Support of Russian Cinema and an honorary award from the German Film Critics' Association.

Ron was also a valued contributor to Kinema for the past fifteen years. 